\title{
Filling the Gaps: Proposed Review to Improve Qatar Environmental Law
}

\author{
Prof. Abdelnaser Zeyad Hayajneh \\ Professor of Law - Advisory Board Member - Centre for Law and Development - College of Law - Qatar \\ University
}

\begin{abstract}
Qatar is a pleasant Arab country in the Middle East with high regional and international profiles. It is a small country in terms of geography and demography and has a relatively modern legal system. The legislative power in the State of Qatar is exercised by his highness the Emir and the Shura Council with certain legislative competences exercised by the government. Qatar's priorities are clear and cover a wide range of aspects, to foster and enhance human, social economic and environmental development and transform Qatar into advanced society capable of achieving sustainable development and securing a high standard of living for its people for generations to come. Many environmental laws and bylaws are now in place in Qatar to protect the environment. These legislative instruments need a full review to ensure efficiency, comprehensiveness. Moreover, the full review of Qatari environmental legislative pack is due to maintain its modernity and conformity with international standards in this regards. This study attempts to outline the main gaps that need actions to achieve Qatar's environmental objectives and meet the state's international commitments.
\end{abstract}

Keywords: Qatar Environmental Law, Environmental Court, Civil Liability, Human Rights, Insurance

DOI: $10.7176 / \mathrm{JLPG} / 91-02$

Publication date: November $30^{\text {th }} 2019$

\section{Contextual Background}

As being, the richest country in the world with a per capita income ranging around \$134. "Qatar has a welldeveloped oil exploration industry where the petroleum industry accounts for $70 \%$ of its government revenue, $60 \%$ of its GDP and $85 \%$ of its export earnings". Therefore, the life is Qatar is pleasant and rewarding although the country is straggling against an extremely difficult climatic and natural conditions, the State of Qatar is doing its best to strike the balance between economic and environmental developments.

Qatar is in an advanced and crucial stage of preparations to host the most spectacular international sports events “The FIFA world Cup Tournament, Qatar 2022" few years ahead, for this and many other reasons Qatar is under the spot ${ }^{2}$. Qatar's success will set an example to all nations on how to manage your recourses, capabilities, prepare and present yourself to the world. Qatar National Vision $2030^{3}$ emphasizes the significance of the environment by setting environmental development as one of the four pillars underpinned the country's integrated and comprehensive developmental targets namely human ${ }^{4}$, social ${ }^{5}$, economic ${ }^{6}$ and environmental development ${ }^{7}$.

The vision outlined many different challenges facing Qatar's environment, which include population growth, air pollution, threats and damage to natural habitats. Qatar approach towards addressing environmental issues is based on acquiring the best available advanced technologies, Adopting strategies to enhance environmental awareness among its population and promote sustainable urban growth. Few years before the issuance of the vision, Qatar has introduced its environmental law in $2002^{8}$, even before that, Qatar has many legal provisions with environmental implications ${ }^{9}$, since 2002 , there has been no amendment or review to the Qatari

\footnotetext{
${ }^{1}$ The Richest Countries in the World, a published report available online at: https://www.worldatlas.com/articles/the-richest-countries-inthe-world.html

"15 fascinating facts about Qatar", Oliver Smith, telegraph New paper, 3 October 2019 https://www.telegraph.co.uk/travel/destinations/middle-east/qatar/articles/facts-about-qatar/
3 Amiri decision No. 44 of 2008 on the endorsement of Qatar National Vision 2030, available online in Arabic at: 3 Amiri decision No. 44 of 2008 on the endorseme

${ }^{4}$ Human Development: The development of the Qatari people to enable them to promote a prosperous society

${ }^{5}$ Social Development: The development of a safe, just society founded on high moral standards and social capable of interacting with different societies playing a significant role in global partnerships for development

${ }^{6}$ Economic Development: The development of a national competitive and diversified economy capable of meeting the needs of the Qatari people both present and in the future and securing high standards of living.

${ }^{7}$ Environmental Development: Management of environment with harmony and balance between economic, social development and environmental protection.

8 Law No. 30 of 2002 Promulgating the Law of the Environment Protection, available online in English at: http://www.almeezan.qa/LawArticles.aspx?LawTreeSectionID=13822\&lawId=4114\&language=en

${ }^{9}$ Qatar has a notably modern legal system, with many law and bylaws being put in place in the last 25 years. For date and information on Qatar legislative frameworks see Qatar Legal Portal (Al-Meezan), which is a comprehensive website that encompasses, inter alia:

1- $\quad$ all in force, amended and abrogated legislations since 1961

2- the judicial judgments- issued by the Court of Cassation which the Technical Office of Supreme Council of the Judiciary has
} 
Environmental Law.

This study suggests that time is suitable to introduce certain amendments to improve the Law and ensure its efficiency. This article attempts to outline the most urgent amendments that the Qatari legislator needs to address. In so doing, the study will apply a descriptive approach, with little explanation or analysis expect when required to clarify issues, ideas and suggestions.

\section{Environmental Law Principles}

It is now well- established that environmental law as a distinct branch of law has certain principles that shape its rules $^{1}$. The main principles of environmental law are sustainable development, Precautionary principle, Polluter pays principle, Environmental impact assessment, Public participation and Common but differentiated responsibilities. $^{2}$

The permanent Constitution of the State of Qatar flagged the protection of the environment in Article 33, which reads as follows: "The State shall preserve the environment and its natural balance in order to achieve comprehensive and sustainable development for all generations"3.

The Article is quiet important in terms of providing for the principle of sustainable development, which is the first environmental law principle. The concept of Sustainable development dominates and outlines all aspects of environmental protection ${ }^{4}$. Sustainable development was first introduced by the by the World Commission on Environment and Development who defined sustainable development as the "development that meets the needs of the present without compromising the ability of future generations to meet their own needs"5. The Qatari legislator seems familiar to the notion of sustainable development; as it appears also throughout the Qatari environmental law no 30/2002 in different contexts.

Article 1 defines the term Environment Development to mean the policies and measures that satisfy the social, cultural, and economical sustainable development requirements in the State, and achieve the objectives and principles invested in the law including; the current and future improvements of the natural habitat, elements and conservation of biodiversity and historical, archaeological and natural heritage in the State.

Furthermore, article 2 set sustainable development as one of the law's objectives; it set out the law' objectives to include Development of natural resources, conservation of the biodiversity and ensure optimum exploitation thereof or the benefit of the present and future generations.

In addition, and to ensure achieving sustainable development, the law imposed certain obligations on the state administrative authorities, i.e.

- Take the necessary measures and precautions to protect the environment, combat pollution, conserve natural resources and ensure their sustainability to meet the development requirements for the present or future generations ${ }^{6}$.

- observe the environmental considerations, giving them top priority, consolidate these considerations in all the phases and levels of planning, and make the environmental planning an integral part of the overall industrial, agricultural, construction and other developmental planning ${ }^{7}$.

- Rationalize the exploitation of the living and non-natural resources to conserve the renewable resources thereof and sustain the use of nonliving resources for the benefit of present and future generations ${ }^{8}$.

- Abide to include the clause of the Environment Protection and Pollution Control in all the local and international agreements and contracts, which could be, upon implementation, harmful to the Environment. These agreements and contracts shall include penalties conditions, and undertaking to

classified, indexed and concluded the legal principles from them

3- the legal fatwa principles issued by the Department of Fatwa and Contracts (a previous department of the Ministry of Justice)

4- legal scholarly references, http://www.almeezan.qa/Default.aspx?language=en

${ }^{1}$ These Principles are derived from the most important international environmental treaties and declarations, for more information, see, Abdelnaser Hayajneh, "Environmental Law, the general theory with explanation of environmental legislation", 2012, Dar Al- Thaqafah, Amman, Jordan.

${ }^{2}$ Abdelnaser Hayajneh, 2012, "Legal Protection for the Environment in Jordan and the United Arab Emirates: Comparative Outline", British Journal of Humanities and Social Sciences, November 2012, Vol. 7 (2), pp 64-87, available online at: http://www.ajournal.co.uk/HSpdfs/HSvolume7(2)/HSVol.7\%20(2)\%20Article\%206.pdf, Most of these principle are now well established, others namely precautionary principle is still debatable. However, it is usually appears in national and international environmental law instruments and the principle of common but differentiated responsibilities is widely appears in international environmental law instrument but may have implications and applications at the national and domestic level.

${ }^{3}$ The Permanent Constitution of the State of Qatar, available online at: http://www.almeezan.qa/LawPage.aspx?id=2284\&language=en

4 "Sustainable development in Qatar: Challenges and opportunities", Renee A. Richer, Richer RA. Sustainable development in Qatar:

Challenges and opportunities, International Review of Law, available online at: http://www.qscience.com/doi/pdf/10.5339/connect.2014.22

${ }^{5}$ World Commission on Environment and Development (WCED), Our Common Future. Oxford: Oxford University Press, 1987 p. 43.

Available online at: https://sustainabledevelopment.un.org/content/documents/5987our-common-future.pdf

${ }^{6}$ Article 3 of the law

${ }^{7}$ Article 4 of the law

${ }^{8}$ Article 5 of the law 
bear the expenses of removing the environmental destruction and damages therefrom ${ }^{1}$.

- Include environmental awareness subjects in all the educational stages. These authorities shall ensure that the curriculum containing these subjects pay adequate attention to the environmental awareness. They shall work to establish and develop specialized institutes in Environmental Science to teach technical cadres. All the Information Authorities shall work to reinforce the environmental awareness programs in different media including the, print, audible visual media ${ }^{2}$.

The precautionary principle is the second principle shaped environmental law rules; the essence of precautionary principle is to anticipate and take action when there is a threat of serious or irreversible damage even if there is no scientific certainty. The Rio Declaration made a clear reference to the precautionary principle in Article 15, which reads as follows: "In order to protect the environment, the precautionary approach shall be widely applied by States according to their capabilities. Where there are threats of serious or irreversible damage, lack of full scientific certainty shall not be used as a reason for postponing cost-effective measures to prevent environmental degradation"3.

As for the precautionary principle, it hardly can be traced within Qatar environmental laws and bylaws in the above mentioned. The law made no particular or express reference for this principle. However, the precautionary approach can be found or derived generally from the application of environmental impact assessment and other articles which provide for certain commitments on the base of precaution ${ }^{4}$.

The case with the polluter pays principle seems slightly different because this principle receives more attention from the Qatari legislator. Throughout the environmental law, many articles provide for criminal punishments and other administrative measures to punish polluters and deter environmental pollution ${ }^{5}$.

The negative point in terms of the application of polluter pay principle is absence of special rules to deal with civil liability for environmental damage. The Qatari environmental laws and bylaws made no single reference for the duty of the polluter to compensate victims of his commissions and /or omissions that resulted in damage to persons or private properties.

This legislative gap is significant since it refers the victims to the general rules of civil liability within the Qatari Civil Law, which may not be suitable to handle the issue of compensation in pollution cases. As per the Qatari Civil $\mathrm{Law}^{6}$, it provides for a fault-based liability regime ${ }^{7}$, with some defenses available under certain conditions ${ }^{8}$.

In terms of environmental impact assessment principle, the Qatari Environmental Law provides for a detailed regime to apply this principle for all activities or establishments with potential environmental adverse effects $^{9}$. Furthermore, the environmental executive list/bylaw went on to prescribe procedures for granting environmental license, appendixes for different types of activities and establishments are also available in the list to determine the level of environmental impact assessment required. This detailed approach on assessing environmental impacts expressly adopt the principle of EIA ${ }^{10}$.

As for public participation, this principle include three elements, first participation in the decision making process, having the right to receive information, and access to justice. The Constitution of Qatar provides for public participation through representatives, namely Ashura Council. Ashura Council has competences in the law-making process and overseeing the government performance.

It would be realistic to admit that certain radical amendments are to be made to enhance the notion of public participation, i.e. the issuance of the General Election Law, and the widening of Ashura Council competences besides strengthening its role in overseeing government's performance.

Moreover, the right to receive information is not recognized by any legal tool within the Qatari legal framework, and as a result public departments are not under a duty to disclose information whatsoever, unless

\footnotetext{
${ }^{1}$ Article 6 of the law

${ }^{2}$ Article 7 of the law

3 Rio Declaration on Environment and Development 1992, United Nations (UN), available online at: http://www.unep.org/Documents.Multilingual/Default.asp?documentid=78\&articleid=1163

${ }^{4}$ Certain Qatari laws are to be applied according to precautionary approach. i.e. Qatari Law on the specifications and standardization system no 4/1990. Which is applied to monitor the products and services within Qatar to ensure its quality and safety to human and the environment. For more information, see "Tracing Environmental Law Principles within the Qatari Legal System", Abdelnaser Hayajneh \& others, British Journal of Humanities and Social Sciences, 2017, Vol. 18(2), available online at: http://www.ajournal.co.uk/HSpdfs/HSvolume18(2)/HSVol.18\%20(2)\%20Article\%209.pdf

${ }^{5}$ Qatari environment Law no 30/2002 dedicated the last chapter to prescribe criminal punishments for wide range of environmental offences.

${ }^{6}$ The Qatari Civil Law no 22/2002, available online in English at: http://www.almeezan.qa/LawPage.aspx?id=2559\&language=en

${ }^{7}$ Article 199 of Qatar Civil Code provides: "Any person who commits an act that causes damage to another party shall be liable to indemnify such damage"

${ }^{8}$ These defenses are, self-defense, force majeure, state of necessity, public servant following the order of competent superior authority (Articles 204-207 of the Qatari Civil Law).

${ }^{9}$ Articles 11-20 of the Qatar environmental law no 30/2002

${ }^{10}$ Resolution No. 4 of 2005 by the Chairperson of the Supreme Council of the Environment and Natural Reserves (SCENR) issuing executive bylaw for law No. 30 of 2002 on environment protection, available online at:
} http://almeezan.qa/LawPage.aspx?id=2108\&language=en 
information disclosed under its discretion. These two gaps are significant in terms of enhancing the participation of the public. However, access to justice seems to be in better situation since the Qatari Constitution provides for access to justice in many Articles that will be referred to in the next section. Qatari legislative bodies are invited to move forward and clearly adopt principles of environmental law, and any relevant interpretation, tools or mechanisms by which these principles can be implemented.

As per the principle of common but differentiated responsibilities, which refer to different contributions in pollution and environmental degradation, this principle is of huge importance in international context, states have common but differentiated responsibilities in the fight against pollution. Therefore, international environmental treaties provide for different obligations according to the state party contribution.

In the same way at the national level, legislator and other competent authorities may classify national sectors according to their environmental impacts and then provides for different standards and legal responsibilities to these sectors. This principle may be fairly observed while Qatar is approaching the establishment of environmental fund; Qatar may also consider imposing green taxes on polluting activities according to their contribution in environmental pollution. Finally, the rules of social responsibilities for commercial corporates may observe this principle ${ }^{1}$.

\section{Environmental human rights}

Human rights are now widely linked to the majority of legal notions, since human rights, literature can provide a solid theoretical base for any legal intercourse. The environment and its protection is not an exception. During the last five decades a huge amount of literature and debates has been developing. In addition, for the time being, there are several international law documents - hard and soft- besides national constitutions and laws provides for a package of human environmental rights. These rights are of substantive and procedural nature.

The main substantive human environmental rights are the right to healthy environment, the right to development, the right to natural resources, and the right to water, whereas the procedural human environmental rights are the right to information, the right public participation, and the right to access to justice.

Exploring the Qatari legal frameworks in different levels reveals the following findings:

First: at the constitutional level, certain rights were mentioned in different level of explicitly as follows:

1- The ambiguous adoption of some rights in an explicit terms, though it may has existence outside the legal context, namely the right to information which has not been established as an actionable right with legal content ${ }^{2}$. However, it may receive application through media and communications. The same situation is applicable to the right to water ${ }^{3}$.

2- The partial and or special adoption of some rights such as the right to healthy environment ${ }^{4}$, the right to natural resources, the right to development.

3- In terms of explicit adoption, procedural environmental rights generally seem to be in a better situation than substantive rights such as the right to access to justice ${ }^{5}$, the right public participation ${ }^{6}$.

Second: ordinary legislative level (Laws and Amiri Decrees)

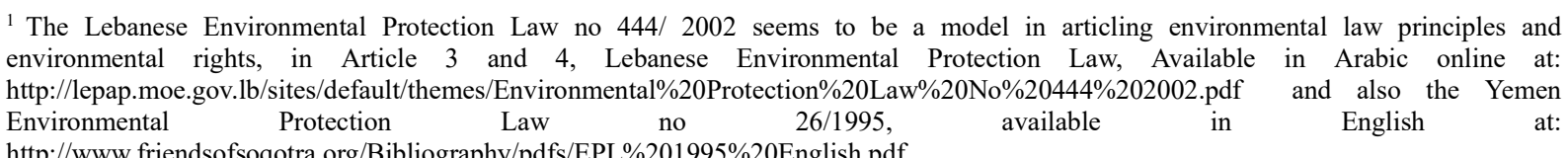

${ }^{2}$ To the date there is no in force legislation or any legal article in the legislative hierarchy in Qatar provide for the right to information. However, the state of Qatar has a very strong media in terms of TV and Radio stations and newspapers. The only constitutional provisions that may have limited implication in this regards are Article 46 of the Permanent constitution of the State of Qatar which reads as follows: "Individuals have the right to communicate with public authorities", and Article 47 which states that: "Freedom of the press and media, shall be guaranteed in accordance with the Law."

${ }^{3}$ In practice, the General Qatari General Electricity and Water Corporation "Kahramaa" responsible for delivering services relevant to water and electricity is applying comprehensive programs for water and power efficiency "Tarsheed", and is endeavoring to ensure a high quality of service in these two vital sectors. For further information see the official website for Kahramaa : https://www.km.qa/Tarsheed/Pages/default.aspx\#front

${ }^{4}$ Article 33 of Qatar Constitution provides that: "The State shall conserve the environment and the natural balance thereof in order to achieve comprehensive and sustainable development for all generations." Moreover, Article 23 provides that: "The State shall foster public health, provide the means of prevention of disease and epidemics, and promote their cure in accordance with the Law." Whereas Article 29 stipulates that: "Natural wealth and its resources are the property of the State, which shall preserve and exploit them in the best way possible in accordance with the provisions of the Law". In comparison see, for example Article 33 of the Constitution of the state of Palestine, which provides that: "The enjoyment of a balanced and clean environment is a human right. The preservation and protection of the Palestinian environment from pollution for the sake of present and future generations is a national duty. Constitution of the state of Palestine, available online at: https://www.constituteproject.org/constitution/Palestine_2005.pdf?lang=en and also Article 5 of the Palestinian environmental Law. Available online at: http://muqtafi.birzeit.edu/pg/getleg.asp?id=13430

${ }^{5}$ Article 135 of Qatar Constitution provides that: "Access to justice shall be guaranteed to all people. The Law shall specify the procedures and manner of exercising this right.", and Article 131, which reads as follows: "Court sessions shall be public except when a court decides, in the interests of public order or morality, to hold them in camera. In all cases, judgments shall be pronounced in an open session".

${ }^{6}$ Articles 76-116 provides in details to different rules govern legislative authority represented in Ashura Council. Which -according to the constitution should be formed of 30 elected members and 15 member appointed by His Highness the Amir. 
Exploring Qatari laws with environmental provisions or implications reveals that there is no explicit reference for human environmental rights per se, rather, there are some provisions which provide for certain rights and mechanisms to enforce these rights, but this tends to be in the general term without having special mentioning or treatment for human environmental rights ${ }^{1}$.

This remark is quiet strange because Qatari laws generally are new and modern, and one may at least expect to see human rights of the third generation.

Third: third level of legislation, bylaws decrees, decisions, and other legislative instruments,

The same above remark is to be declared here, bearing in mind that the level of legislation is not appropriate to include human rights, because legislative hierarchy does not properly support rights mentioned at this level; since it is the lower level of legislation and can be overruled by legislative provisions from upper levels.

\section{Civil Liability for environmental damage}

Exploring the Qatari Environmental Law reveals that the law do not provide for special rules to cover civil liability arise from pollution. However, the law provides for criminal and administrative liabilities. Having said that, the reference to civil liability in terms of environmental damage cases is to be made to the Qatari Civil Law no $22 / 2004$ that provide for a comprehensive regime to govern tort or civil liability for damage of types in Article 199-219

The general rules of civil liability provide for a fault-based liability doctrine. Therefore, fault in the part of defendant is a crucial element that triggered the liability rules. Although civil cases are rare before Qatari court in environmental damage events, but one can predict that applying general rules of civil liability will present various difficulties, i.e. proving fault in the defendant part, proving causal link between defendant's conduct and plaintiff injury to the extent that make the conduct the natural cause of plaintiff loss.

Special rules to deal with harms and damage resulting for pollution and environmental wrongful conduct and compensation thereof are important and needed to implement polluter pays principle via civil law mechanisms, therefore, Qatar is encouraged to introduce its special regime for civil environmental liability. This proposed regime shall pay due consideration to these issues, particularly the base of liability, burden of proof, standing $^{2}$, prescription, assessing environmental damage and compensation, and insurance against liability.

This proposed civil liability regime would indeed be the real reflection to principle 13 of the Rio Declaration, which provides that: "States shall develop national law regarding liability and compensation for the victims of pollution and other environmental damage. States shall also cooperate in an expeditious and more determined manner to develop further international law regarding liability and compensation for adverse effects of environmental damage caused by activities within their jurisdiction or control to areas beyond their jurisdiction". Such a move also will save Qatar pioneering trend in the field of conserving the environment and adopting sound policies and laws to achieve sustainable developments goals.

\section{Special Environmental Court}

Qatar judiciary is an independent public authority, divided into ordinary courts having jurisdiction over civil and commercial matters, and family court specified in family affairs and disputes ${ }^{3}$, and the Supreme Constitutional Court established by special law to have jurisdiction in constitutional disputes besides other limited competences ${ }^{4}$. Within the ordinary branch of judiciary, there is two main courts of first instance, Partial Circuit Court and grand or Plenary Court with certain jurisdictions in civil, commercial and criminal matters. Other special courts are also operated in the field of investment and financial disputes ${ }^{5}$.

To date, Qatar does not establish special environmental court to have jurisdiction over environmental violations and environmental damage disputes. The case to establish special environmental court within the Qatari Judiciary can be established for the following reasons;

1- The special characteristics attached to environmental harms, in terms of its nature, sources, and effects; certain environmental harms are latent and may not appear until long time since it occurred. Other environmental harms may occurs because of multiple sources, and finally there where cases of environmental harm affects indefinite victims or cause damage to unowned environment.

2- The heavy burden of the ordinary courts, which may affect its ability to deliver justice in a due process manner.

\footnotetext{
${ }^{1}$ One may cite many laws in this regard, i.e. Qatari Penal Code, Environmental Law, Civil and Commercial Procedures Law, etc.

${ }^{2}$ It is interesting that certain Arab Environmental Laws provide for an actionable right for every citizen for file or follow any legal proceedings in the case of environmental damage regardless of any personal interest or proprietary rights, see for example Article 3 of the Palestinian environmental Law. Available online at: http://muqtafi.birzeit.edu/pg/getleg.asp?id=13430

${ }^{3}$ The law of Civil and Commercial Procedures no13/1990, http://www.almeezan.qa/LawPage.aspx?id=2492\&language=en

${ }^{4}$ The Law of the Supreme Constitutional Court no 12/2008, http://www.almeezan.qa/LawPage.aspx?id=2486\&language=en

${ }^{5}$ Civil and Commercial Court at Qatar Financial Centre Regulatory Authority, which has certain jurisdiction as per the QFRA law. https://www.qicdrc.com.qa/sites/default/files/s3/wysiwyg/qfc_civil_and_commercial_court_regulations_date_of_issuance_15_december_201 0 0.pdf
} 
3- The technical difficulties usually associated with environmental damage cases; this technicality requires a well-trained judges, lawyers and expertise to consider and review these cases in its all aspects.

4- Qatar presents itself to the world as a model in the region, in Sports and good governance for example, establishing special environmental court will not be an exception to the Qatari presentation. This special environmental court will be leading and pioneer and will pave the way to imitate and utilize the Qatari experience it reviewing environment related disputes.

There will be certainly some requirements for such court establishment; the most important are having qualified staff capable to deal with environmental violations and environmental damage cases efficiently; this particular requirement need specialized educational and training programs to ensure that human recourses will be available in the due course. Administrative support and logistic facilities will also be easy to guarantee the set-up of the environmental court ${ }^{1}$.

To realize this suggestion, Qatari legislator needs to enact special law, to determine the court formation and jurisdiction, procedures to be followed before it, timeline to issue it judgements and the legal ways to challenge its decisions if applicable. An alternative approach may be to amend the current Environmental Law to add new chapter to the same effect.

Some important features in the regard is the admissibility of class actions, which refer to the case where multiple plaintiffs or defendants are involved, and the rules of prescription to allow cases regardless of the traditional rules in the civil or criminal proceedings.

\section{Criminal policy in environmental law}

Although Qatari legislator provides for many environmental crimes, and assigned relatively sufficient punishments for them, but the criminal policy throughout the law was not clear, nor it is easy, many crimes were gathered in the same article and with certain punishment. The concerned persons have to refer to many articles to understand the criminalized act or omission, and find out the assigned penalty. Furthermore, in the case the legislator decide to amend the article which include punishments, due consideration is needed to ensure that the amendment is reasonable; because such amendment may affect different environmental violations.

It is worth mentioning that Qatar Criminal Law introduced alternative punishments under certain conditions and leave it to the court's discretion to impose such punishments where it consider these alternative punishment are sufficient. The significance of such approach is that traditional punishment -financial fines, and imprisonment- usually applicable to punish environmental violations may not be suitable in environmental context; since there will be no direct effect for these punishment on the affected environment or victim.

\section{Environmental fund}

Environmental fund is an idea refers to special fund established to cover victims of environmental damage or environment per se where the polluter remains unidentified or where there is no eligible plaintiff to claim compensation since damage affects unowned environment ${ }^{2}$. The traditional rules of civil liability strictly require personal interest for the plaintiff in the civil action to be able to have locus standi "standing"3. There where cases when the damage affects the unowned environment, in this case there will be no eligible plaintiff to stand for the environment and claim compensation because the rules of civil procedures render such case inadmissible. Its either grant specific entities or interest groups the right to defend the environment and claim damage to restore environmental harms or establish environmental fund to receive compensation to this end.

Moreover, there will be cases where the defendant polluter is identified and the plaintiff suffers personal injury or loss but the requirement of fault in the defendant side or causation hampered the plaintiff from receiving the due compensation. This usually happens when the plaintiff fails to prove the polluter's fault or when he fails to prove that the polluter's commission or omission is the cause for his injury or loss. Unfortunately, applying the traditional rules to these situations will not help justice prevail.

The principles of justice in any good society require that each victim must receive fair compensation for his suffering and that the good society with conscious will not accept any situation otherwise ${ }^{4}$. The legal thought

\footnotetext{
${ }^{1}$ For more details on the requirements of environmental courts' establishment see Abdelnaser Hayajneh, "Special Judicature, Again and Again: Does Jordan Need to Establish Special Environmental Court?”, European Journal of Social Sciences - Volume 14, Number 2 (2010), available online the author research gate:https:/www.researchgate.net/publication/294414380_special_judicature_again_and_again_Does_Jordan_need_to_establish_special_en vironmental court

${ }^{2}$ Jordan, Lebanon and Yemen for example established National Environmental Funds, their experiences need to assessed and improved. Qatar is encouraged to establish its national environmental fund with even more advanced approach than the current comparative experiences. ${ }^{3}$ Article 1 of The Qatari Civil and Commercial Procedures Law no 13 /1990 provides that: "No claim or defense shall be allowed unless the person making such a claim or defense has an existing and legal interest recognized by the law. However, a possible interest shall be sufficient if the object of the claim is a precaution against imminent damage or to ascertain a right where the disappearance of evidence at the time of dispute is feared." Qatari Civil and Commercial Procedures Law no $13 / 1990$ available in English on line at: http://www.almeezan.qa/LawPage.aspx?id=2492\&language=en

${ }^{4}$ From the literature of the late Prof. Ali Negida, College of Law, Qatar University.
} 
creates the idea of compensatory fund to settle legal rights and obligations where the general liability rules fails to do justice. The creation of collective compensatory mechanisms such as insurance compulsory or complementary, and collective funds with special objectives and arrangements to achieve these objectives. The proposed fund will help compensating victims of pollution where the polluter is unidentifiable, or where no fault was proven in the defendant' part, or where it is ruled that the plaintiff is not eligible of damages due to the lack of standing.

Another close issue to environmental fund is the regime of compulsory insurance that will enable victims of pollution to receive redress especially when the polluter is not able to afford compensation due to his insolvency or his weak ability to afford monetary compensation.

To date there is no compulsory insurance against civil liability in general ${ }^{1}$. In environmental damage cases, certain complications may result in the plaintiff's failure to establish his case against the polluter. Therefore, collective compensatory mechanisms may guarantee justice by compensating victims of pollution. Under certain conditions and qualifications, Qatari legislator is encouraged to introduce a compulsory insurance regime for enterprises and corporations whose activities are likely to cause environmental damage.

\section{Financial and economic incentives, social responsibility rules}

Applying the law to achieve environmental objectives is not a new practice, law has been put in place to enhance environmental sustainability and deter pollution during the last several decades. The Stockholm Conference and Declaration 1972 assign law, education and science to face environmental challenges.

Laws play vital role in solving human problems, by means of organization, regulations and punishments. However, the law can also apply a more positive role in handling problems; financial and economic incentives can play a tangible role in enhancing environmentally friendly conducts. Stating environmental initiatives and restoration as accredited social responsibility activity will encourage companies in public and private sectors to launch and implement environmental protection initiatives and programs. Certain governmental departments and institutions such as schools, universities can also be required to participate in environmental activities as part of its assessment measures.

The law can also provide for tax exemption, free media advertising coverage, inclusion in a white list establishment, , eligibility and admissibility to governmental tenders as incentives for any having active role in protecting the environment. These are only examples on what the law can do in activating and accelerating environmental private work, and the door will always remain opened for new and creative incentives.

Different laws may provide for financial and other incentives, company law, income tax law, criminal law and other relevant laws. These laws shall provide specific rules to apply and/or enhance incentives roles in promoting sound environmental practices and conducts.

\section{Findings and recommendations}

At the end of this paper, the study realize that Qatar has shaped its environmental policies and strategies in a reasonable manner according to the level of interest and environmental awareness of its public policy makers. However, Qatar needs to review and adapt its environmental law policies to ensure effectiveness. Qatar is moving forward to setup an advanced model in the field of sustainability and human development, this will certainly encourage conducting a full and due review for Qatari environmental package, at the legislative and practical levels ${ }^{2}$. Certain gaps are still to be filled; other issues need to be assessed and may require legislative interference.

- Most gaps within the Qatari Legal and environmental frameworks seem to be theoretical, Qatar environmental practices are interestingly advanced, and the mentioning of some environmental law principles and human environmental rights will add only a theoretical framework to highlight Qatar pioneering status in the field of environment and sustainability. An actionable right to healthy environment is most pressing one since it will pave the way in front of individuals and environmental interest groups to defend the environment apart from personal interest and property.

- Qatari legislator needs to introduce special rules to cover civil liability for environmental damage. These rules must deal with certain complications and deficiency within the general rules of tort to accommodate specialties of environmental damage cases. The most important issues that the proposed

\footnotetext{
${ }^{1}$ It is significant to mention that the Qatar Law relevant to proof through experts stipulates that any experts who wish to register officially as an authorized expert must submit proof of having insurance against liability arise out of his fault in the course of duties performance. Article 11 of Qatari Law no $16 / 2017$ on the organizing of proof through Experts, available online at: http://www.almeezan.qa/LawPage.aspx?id=7364\&language=ar, another example of compulsory insurance against civil liability in Article 8/5 of the Law no. (19) of 2007 Regarding the Traffic Law, http://www.almeezan.qa/LawPage.aspx?id=3993\&language=en

${ }^{2}$ This due review needs to be comprehensive and gradual considering Qatar's special environmental challenges besides national community characteristics and priorities. Abdelnaser Hayajneh, "Creativity vs. Imitation: Understanding Diversity and Legislative Identity in the State of Qatar", Global Journal of Politics and Law Research, Vol.7, No.7, pp.78-85, November 2019, available online at: https://www.eajournals.org/wp-content/uploads/Creativity-vs.-Imitation.pdf
} 
regime must sort out are, the base of liability, burden of proof, the issue of standing, laps of time and its effect on the plaintiff right to bring the action, and methods to assess environmental harms and calculation of damages.

- Establishment of Special Environmental Court in Qatar is also recommended and due. Some prerequisites are available and may only need a legal framework; Qatari competent authorities in the due course can afford others relevant to the administrative and logistic requirements.

- A compulsory insurance regime can fill the gap in the case the polluter is insolvent or lack financial asset to pay the awarded compensation. Such regime would not be novel as Qatar recently introduced such mandatory insurance against liability in its legal framework.

- Public Environmental Fund will add a lot to Qatar ability to launch environmental restoration and cleanup projects. Such fund require a legal framework with certain basic rule.

- A due review for the criminal policy applied within Qatari Environmental Law and other laws criminating environmental violations to ensure simplicity, cohesion, and comprehensiveness.

- Adopting creative criminal approach by employing alternative punishments, such as social services, environmental work, forestation, sites clean up, eligibility and admissibility to governmental tenders, etc.

- Appling financial and economic incentives in the field of environmental protection, tax exemption, social responsibility for corporates, media coverage and advertising campaigns, environmental white and black list, eligibility and admissibility to governmental tenders. These are only examples, and laws may provide for creative kinds of incentives.

\section{References}

- Abdelnaser Hayajneh, "Environmental Law, the general theory with explanation of environmental legislation", 2012, Dar Al- Thaqafah, Amman, Jordan

- Abdelnaser Hayajneh, 2012, "Legal Protection for the Environment in Jordan and the United Arab Emirates: Comparative Outline", British Journal of Humanities and Social Sciences, November 2012, Vol. 7 (2), pp 64-87, available online

at: http://www.ajournal.co.uk/HSpdfs/HSvolume7(2)/HSVol.7\%20(2)\%20Article\%206.pdf

- Abdelnaser Hayajneh, "Special Judicature, Again and Again: Does Jordan Need to Establish Special Environmental Court?”, European Journal of Social Sciences - Volume 14, Number 2 (2010), available online the author research gate:https://www.researchgate.net/publication/294414380_special_judicature_again_and_again_Does_Jorda $\mathrm{n} \_$need to establish_special_environmental_court

- Abdelnaser Hayajneh, "Creativity vs. Imitation: Understanding Diversity and Legislative Identity in the State of Qatar", Global Journal of Politics and Law Research, Vol.7, No.7, pp.78-85, November 2019, available online at: https://www.eajournals.org/wp-content/uploads/Creativity-vs.-Imitation.pdf

- World Commission on Environment and Development (WCED), Our Common Future. Oxford: Oxford University Press, 1987 p. 43. Available online at: https://sustainabledevelopment.un.org/content/documents/5987our-common-future.pdf "Sustainable development in Qatar: Challenges and opportunities", Renee A. Richer, Richer RA. Sustainable development in Qatar: Challenges and opportunities, International Review of Law, available online at: http://www.qscience.com/doi/pdf/10.5339/connect.2014.22

- Amiri decision No. 44 of 2008 on the endorsement of Qatar National Vision 2030, available online in Arabic at: http://www.almeezan.qa/LawPage.aspx?id=2845\&language=ar

- The Richest Countries in the World, a published report available online at: https://www.worldatlas.com/articles/the-richest-countries-in-the-world.html

- “15 fascinating facts about Qatar", Oliver Smith, telegraph New paper, 3 October 2019 https://www.telegraph.co.uk/travel/destinations/middle-east/qatar/articles/facts-about-qatar/

- Qatar Legal Portal, http://www.almeezan.qa/Default.aspx?language=en

- Law No. 30 of 2002 Promulgating the Law of the Environment Protection, available online in English at: http://www.almeezan.qa/LawArticles.aspx?LawTreeSectionID=13822\&lawId=4114\&language=en

- Rio Declaration on Environment and Development 1992, United Nations (UN), available online at: http://www.unep.org/Documents.Multilingual/Default.asp?documentid=78\&articleid=1163

- The official website for Qatar Financial Centre Regulatory Authority, http://www.qfcra.com/enus/SitePages/Home.aspx

- Qatari Law no $16 / 2017$ on the organizing of proof through Experts, available online at: http://www.almeezan.qa/LawPage.aspx?id=7364\&language=ar

- Law no. (19) of 2007 Regarding the Traffic Law, 
http://www.almeezan.qa/LawPage.aspx?id=3993\&language=en

- The Permanent Constitution of the State of Qatar, available online at: http://www.almeezan.qa/LawPage.aspx?id=2284\&language=en

- Constitution of the state of Palestine, available online at: https://www.constituteproject.org/constitution/Palestine_2005.pdf?lang=en

- Palestinian environmental Law. Available online at: http://muqtafi.birzeit.edu/pg/getleg.asp?id=13430

- Lebanese Environmental Protection Law, Available in Arabic online at: http://lepap.moe.gov.lb/sites/default/themes/Environmental\%20Protection\%20Law\%20No\%20444\%202002 .pdf

- Yemen Environmental Protection Law no 26/1995, available in English at: http://www.friendsofsoqotra.org/Bibliography/pdfs/EPL\%201995\%20English.pdf

- General Qatari General Electricity and Water Corporation "Kahramaa", official website: https://www.km.qa/Tarsheed/Pages/default.aspx\#front

- Resolution No. 4 of 2005 by the Chairperson of the Supreme Council of the Environment and Natural Reserves (SCENR) issuing executive bylaw for law No. 30 of 2002 on environment protection, available online at: http://almeezan.qa/LawPage.aspx?id=2108\&language $=$ en 